\title{
H.G. Stoker as mentor
}

\author{
N.T. van der Merwe \\ Departement Filosofie \\ Potchefstroomse Universiteit vir $\mathrm{CHO}$ \\ POTCHEFSTROOM
}

\section{Twee paaie na Stoker as leermeester}

Woordeboeke omskryf mentor as 'n ervare en vertroude raadgewer, gids en leidsman, soos die vriend van Ulysses uit die Antieke verhaleskat. Die etimologie kan ons moontlik ook nog 'n skakel met denke bied. Die kernvraag is dus hoe H.G. Stoker as hoogsgeskoolde akademikus in sy beroep leiding gegee het, watter soort raad en waarskuwinge hy as kundige dosent aan sy studente gebied het, watter koers hy as ervare gids aangedui het - én hoe hy denkend uitvindinge gestimuleer het. Hiervan vorm sy onderrig (en onderrigbeleid) 'n essensiële komponent, maar dit is 'n breër vraag as net wát sy onderrig behels het. Dit lyk vir my daar is basies twee weë oop om af te tas wat Stoker as universiteitsdosent met die resultate van sy wysgerige denke aan ander wou tuisbring: dit wat hy met voordragte aan sy hoorder-student vertel het, en dit wat hy met geskrifte aan sy leser voorgehou het. Ek sal albei weë saam-saam bereis, want albei was Stoker ems, ja 'n roeping, al was die didaktiese moment verskillend in elk omraam - en al is dit moeiliker om die didaktiese bedoeling uit die geskrewe woord te distilleer.

Bowendien dek albei 'kanale' 'n besonder lang periode, sodat - al is dit hier nie moontlik nie - 'n mens eintlik ook behoort na te gaan in watter mate daar deur die loop van jare 'n groei of wending plaasgevind het en hoe dit deur sy studente ervaar is 1 . Byna vier dekades lank het prof. dr. H.G. Stoker naamlik voltyds aan die PUK en later PU vir CHO wysbegeerte gedoseer - aanvanklik tewens psigologie. Na sy emeritaat in 1964 het hy voortgegaan om nog etlike jare in deeltydse hoedanigheid as ereprofessor aan sy alma mater en aan die Randse Afrikaanse Universiteit sy gedagtes met ander te deel

1 'n Ondersock van laasgenoemde faset is nog onderweg en moet hier agtenweë bly. Hicrdic bcknopte skets, saamgestcl op versock van dic redaksic, stcun in bclangrike mate op my artikels "By H.G. Stoker in-dic-lecr" (Perspektief, 3 (2\&3), 1964:9-17) cn "Prof. dr. H.G. Stoker (4 April 1899 - 16 Mci 1993) - 'n Huldcblyk" (Koers, 58 (3), 1993:267-271). 


\section{Publikasies as loergat}

Wat het Stoker van belang geag vir die aandag, lering en vorming van andere? Let 'n mens op die temas van sy publikasies, blyk Stoker telkens opnuut betrokke by en geboei deur onder andere die aktualiteit en omvattendheid van die Calvinisme; die deurslaggewende rol van lewens- en wêreldbeskoulike vooronderstellinge en waardes in wetenskap en lewenspraktyk; die inherente aard en potensiaal van Christelike wetenskap en spesiaal die verhouding van Skrifgeloof en wetenskapsbeoefening; beginsels en hooflyne van die Calvinistiese wysbegeerte in die kaleidoskoop van 'n 'skeppingsidee'; menslike vryheid, verpligtinge en behorenseise; die grondprobleme van die etiek; kosmiese gebeure, tyd en menslike handelinge, ensovoorts. In dit alles wou hy aantoon dat besinning oor Gods skepping diep sinvol en ryklik lonend is - en dié boodskap het in woord en letter by ' $n$ groot aantal belangstellendes uitgekom en inslag gevind. Selfs die ontwrigtende jare in die Koffiefonteinse konsentrasiekamp gedurende die Tweede Wêreldoorlog het 'n geleentheid geskep om op totaal ander wyse as dosent te figureer en lewenslange intellektuele geesverwante en medewerkers te vorm.

\section{Betekenis van die 'skeppingsidee'}

Self werk hy veral vanaf die dertigerjare skerpsinnig, kreatief en heel oorspronklik 'n eie nuanse uit, bekend as die 'Wysbegeerte van die Skeppingsidee', waarvan die tweedelige versamelwerk Oorsprong en rigting (1967 en 1970) 'n goeie deursnit bevat. Hiermee het hy dosyne studente - en ook belangstellende akademici versprei deur die land - geboei en talle begeester vir wetenskaplike werk in die lig van Gods Woord. Op hul beurt het verskeie van sy oudstudente wat met die loop van tyd aan verskillende Suid-Afrikaanse universiteite en kolleges benoem is, met entoesiasme die grondprobleme van die filosofie en die grondslae van die vakwetenskappe in 'n Christelike perspektief verder ondersoek. Menige vakgenoot het die denkprodukte van Stoker as in hoë mate solied, oorspronklik en relevant geëvalueer. Sy uitset was bowendien merkwaardig dinamies: oor meer as vyf dekades het dit 'n gestadige voortgang en groei getoon, ook 'n ontwikkelingsgang waarvan die kontoere moontlik nog verder afgetas kan word. Sy filosofiese en intellektuele belangstelling was byna sonder grense en sy beoordeling van die bydraes van ander akademici ruim en erkentlik. Vir sy studente was dit 'n besonder belangrike rigtingwyser en kontrolekriterium. Twee ander fasette van sy benadering is eweneens kenmerkend: eerstens die moeite wat hy voortdurend gedoen het om aan te toon dat 'n Christelike siening in vergelyking met ander standpunte en skole besonder ruim en omvattend is en tweedens dat elke ondersoek van die werklikheid rekening moet hou met die kwaad en dus die verskeurde en versteurde karakter van die skepping. 
Verskeie geleerdes wat uit beginsel met hom van insig verskil het, het tog 'n groot respek vir sy intellektuele belesenheid, logies skerp insig, opsigtelike vakbekwaamheid en eerbied vir die feite gekoester. Sy passievolle speurtog na nie net die mees opsigtelike maar sover moontlik alle feite, ja die volle verskeidenheid, voordat tot 'n beoordeling gekom word, het in breë kring respek afgedwing en ook menige teëstander tot versigtigheid en waardering gestem.

\section{4. 'n Skrywer-spreker}

Probleem en motief van wysgerige studie het by Stoker 'n stempel op sowel sy skriftelike as doseeraktiwiteit gedruk, en wel 'n stempel van 'n besondere slag: uit studie ontspring 'n skrywer-spreker - in die publikasie spreek die dosent en in die voorlesing is die skrywer aanwesig. 'n Enkele keer sou die balans dalk 'n bietjie na die een of ander kant uitswaai, maar al gou dring die swaartekrag van 'n 'denke-met-die-tikmasjien' tot 'n sekere ekwilibrium. Dit is daarom eintlik ook nie korrek om van 'n 'voorlesing' te praat nie, want Stoker het nooit sy gedagtes bloot voorgelees nie. Nee, telkens moes dit weer 'n kreatiewe worsteling met wysgerige probleme word waarvan die verloop, ontwikkeling en eindpunt nie vooraf vas staan nie. Helder staan my voor die gees hoe Stoker die problematologie van sy Die grond van die sedelike in die klas kon behandel asof dit nog op skrif gestel moes word en die indruk by ons lewend was dat sy insigte hier en nou in die ontplooiing van die voordrag gebore word. Dikwels het ' $n$ voordrag dan ook gestalte aangeneem vanaf 'n skematiese skets met hoofpunte en sleutelbegrippe.

\section{Die klassituasie: 'n dialektiek van persoons- en saakliefde}

Dit was in kamer 8 van die noordelike vleuel van die destydse hoofgebou dat ons groentjies in die jare kort na die selfstandigwording van die PUK gekonfronteer is met die fenomeen filosofie - anvanklik weliswaar ' $n$ vreemde verskynsel, fassinerend en inspirerend maar tegelyk obsiderend. By wie sou dan ook nie - met Stoker as gids in die kronkelgange van daaglikse verwondering - die eeu-oue liefde vir die wysheid al gou ontbrand nie? Dit kon nie anders nie as dat die dosent in die bewussyn van sy studente bly natril. Dikwels het hierdie entoesiasme gedurende die pouses tussen lesingperiodes by menige student geïntensiveer en is die begeerte na wysheid geaktualiseer in 'n soek en 'n vind, al was dit natuurlik meer as eens blote eendags-studentewysheid.

Stoker moes en kon saamleef met ons subjektiewe gedraginge en soms beperkte ontvanklikheid. Maar hoe is dit begryplik dat hy nooit aan die versoeking toegegee het om oor die wondersoete inslaap by die laatmiddagsessie te filosofeer nie? Het die psigoloog of die opvoedkundige dalk daar die deurslag gegee? Hoe ook al, al het ons dikwels nie saam met hom die hoogtes van wysheidsélan bereik nie 
en meer as eens soos Sisuphos vir die hoeveelste keer van die heuweltop afgegly, ons het wel goed besef dat dit jare van Stoker se ryp doseerervaring was en ons die voorreg het om in die klas van 'n meester te sit. Historiese perspektief verg dat ek meteen moet byvoeg: ook leerlinge uit die twintigerjare verseker my dat die entoesiasme in die klaskamer toé nie minder was om die dosent die ploegkuns diep in soliede grond van massas feite en die sweefkuns hoog in die abstrakte ruimte van die teorie te sien beoefen nie! Eweneens het studente uit alle periodes ervaar dat en hoe Stoker in sy akademiese taak opgaan - tyd vir allerlei burgerlike en sosiale afleidinge en statussimbole was daar nie, wel by geleentheid vir sinvolle ontspanning in die huislike kring.

Stoker se publikasies word gekenmerk deur naaldskerp onderskeidinge, begripsverhelderinge en 'n oog vir relevante detail. Sy lesings was 'n fyn spel van saaklike inligting, afkap van minder belangrike gegewens aan die omtrek met ' $n$ telkens skerper beitel en oopkap van onverwagte horisonte in 'n diskussie-omlysting. Nieteenstaande die didaktiese en intellektuele uitdaging wat die skerp logiese verstand van die dosent gestel het, kan ek my geen jaar herinner waar 'n louter serebrale onderwerp opgeduik het nie. Daarvoor was Stoker te persoonlik betrokke by die temas van die akademiese jaar: telkens sou daar van jaar tot jaar weer 'n teoretiese simbiose ontplooi tussen dosent en sowel onderwerp as gehoor. Dit kom my voor of hierby 'n rigtinggewende dinamiek van 'n dieperliggende grondmotief aanwysbaar is, 'n dryfveer werksaam besonderlik in die sentrale tema van sy etiek, wat ek generaliserend sou kon formuleer as: van persoonsliefde tot saakliefde. Eintlik sê ek dit só nog nie goed nie - tussen dié twee pole was immers 'n magnetiese veld, waarby Stoker haarfyn die belange van tema en leerling afgeweeg het en in 'n dialektiese slingergang nou ter wille van 'n begrip van die problematiek 'n diskussie sou uitlok, dan weer met die oog op die steeds maar te beperkte tyd ons vrae en mentale moeilikhede sou antisipeer en halfweg tegemoetkom.

\section{Stoker se basiese werkswyse}

'n Sleutel tot die 'Stoker-metode' is myns insiens reeds aanwesig in die proefskrif van 1925, Das Gewissen. Ek sou my nie daaraan wou waag om die eminente kwaliteite van dié studie te probeer determineer nie, kwaliteite waardeur dit selfs byna vier dekades later nog by J. Stelzenberger (Conscientia bei Augustin, 1963) 'n sentrale plek onder die basiese literatuur inneem. Tog lyk die eienskappe my wel evident: 'n breë voorstudie, toespitsing op die essensie en 'n grondige bewerking tot (skematiese) oorsigtelikheid. Met 'n soortgelyke aanpak is die weg vry om in opeenvolgende lesings die hooflyne naaldskerp uit te kerf, kortliks met die historiese ontwikkeling van die vraagstuk te konfronteer, en teen dié agtergrond 'n eie visie voor te dra. Ook latere groot studies soos dié oor die vryheidsprobleem, tydsvorme, wetenskapsteorie, ensovoorts, toon 'n metodiese oriëntasie 
ten aansien van die vernaamste gesigspunte van die betrokke tema deur andere opgemerk; ' $n$ histories verdiepte insig ten aansien van die relevante vondste en insigte van die vernaamste wysgere in die verlede; dan al worstelend 'n ontdekking van die juistheid of eensydigheid van die betrokke opvattinge en 'n geleidelike ontplooiing van eie visie op die saak ${ }^{2}$. Hierdie strategie is met groot sukses prakties met studente, veral nagraadse studente, geïmplementeer.

Persoonlik het ek in 1956 kon meemaak met hoe 'n inset van kragte en teen watter tempo dié toepassing kon verloop, toe Stoker hom vir die eerste keer intensief spesiaal met taalfilosofie gaan besig hou het. Drie weke het verbygegaan onder intense studie van 'n geselekteerde groep oriënterende geskrifte. Hieruit is daarna ' $n$ aantal hoofprobleme vir detailondersoek afgesonder. $\mathrm{Na}$ twee weke was Stoker gereed met 'n voorlopige program of skema van die belangrikste verskeidenheid sover opgemerk, en 'n aanduiding van die weg waarlangs ' $n$ poging aangewend sou word om tot 'n eie opvatting te probeer kom. Nog twee weke later diep in die nag het die ontdekking van 'n eie visie deurgebreek en met drie dae gekonsentreerde arbeid is die eerste proef op die tikmasjien uitgehamer. Die hooflyne was daarmee uitgestippel en die volgende maande sou die breëre uitwerking en afronding bring, soms met verdiepte voortgesette ondersoek of ook wysiging en korreksie. Die gloed wat die aha!Erlebnis daardie aand begelei het en die vertrek geheel gevul het toe Stoker my na sy studeerkamer ontbied en sy vonds met my gedeel het, laat 'n lewenslange hunkering om tog maar 'n skilder te kon gewees het!

Kenmerkend was daarby die tipiese wyse waarop Stoker weet om binne die raamwerk van eie filosofie 'n oog te behou vir die moontlikhede deur ander wetenskaplikes ontgin - deur hom as waarheidsmomente geïdentifiseer en erken. Treffend was ook die mate waarin 'n aanvanklike stimulus uit die filosofie van $\mathrm{H}$. Bavinck onverwagte perspektiewe op die gebied van die taalfilosofie ontplooi het. Konfrontasie met ander teorieë, byvoorbeeld dié van $\mathrm{K}$. Bühler, kon soms tot die omvang van 'n aparte monografie uitgroei en verrassende resultate vir sy eie sistematiek oplewer.

2 Dic volgorde van die boustene kan uiteraard wissel. Vergelyk byvoorboeld sy cie meer sistcmatics begronde beskrywing van sy werkmetode ('dic suiwerste vorm van sintese') in sy inougurcle rede Die kriesis in die teenswoordige Sielkunde. Pretoria : Van Schaik, 1930:25. 


\section{Kosmiese verskeidenheid as rigsnoer vir historiese en sistematiese ondersoekinge}

Met presies 'n jaar het ek as beginneling die voorreg misgeloop om Stoker historikale ontledinge te sien doen, want gedurende die vyftigerjare het die doseer van die vak Geskiedenis van die Wysbegeerte geleidelik op die skouers van sy kollegas Taljaard en Du Plessis begin oorgaan en het Stoker sy kragte gekonsentreer op die breë sistematiek van die filosofie. Van 'n ouerejaars-vriend kon ek nog wel die klasaantekeninge oor capita selecta uit die Geskiedenis van die Wysbegeerte leen. Vir sover hieruit 'n afleiding moontlik is, het Stoker ook hier 'n so helder moontlike interpretatiewe weergawe van die bedoelinge van die besproke outeurs beoog, met kritiese opmerkinge en verhelderinge uit eie filosofie, 'n peiling van die betekenis van die bydraes en - soos ek verneem het boeiend en gloedvol voorgedra.

Met die verloop van tyd is Stoker se aandag steeds intensiewer gerig op die uitbou van 'n eie sistematiek. Ek het 'n indruk dat sy talente ook in besondere mate juis op hierdie gebied lê. Nie sonder rede nie sentreer sy belangstelling steeds weer in kosmologie, lewens- en wêreldbeskouingsleer, kultuurfilosofie, etiek, kennis- en wetenskapsleer, en so meer. Dié faktor skyn my mede van belang vir 'n waardering van Stoker as leermeester. Dat grondige bestudering van die Geskiedenis van die Wysbegeerte aan 'n inrigting vir Christelike hoër onderwys onmisbaar is - ook en veral in 'n tyd soos die huidige met sy gereduseerde waardering vir die geskiedenis as sodanig - behoef geen verdere betoog of nadere toeligting nie. Stoker het dit steeds as vanselfsprekend beskou. Wél lyk dit my nie sonder betekenis nie om hier nog spesiaal te wys op die belang daarvan dat juis by die vestiging en uitbou van 'n wysgerige departement die horisonte in die sistematiek so wyd moontlik uitgespan is.

Stoker het sy studente nie geslyp deur aandag aan slegs een of twee lieflingsfigure nie, en het ook nie oor net een lieflingstema geskrywe nie. Ook in die wysbegeerte het die groot verskeidenheid hom bly boei: die 'veelkleurige wysheid van God' (wat in Stoker se besondere toepassing van Efesiërs 3:10 op die onmeetlike verskeidenheid van die skepping, 'n grondpyler van sy denke geword het) was hierby steeds vertrek- en rigpunt. Deur aanleg en vorming was hy in 'n besondere posisie om sy leerlinge ten aansien van die totaalveld van die wysbegeerte te oriënteer en tewens die besef wakker te hou dat daar ook lakunes is wat om aandag roep. Vandaar dat Stoker ook sy leerlinge kon inspireer tot ' $n$ belangstelling vir die filosofiese problematiek van die geskiedenis, taal, kuns, godsdiens en soveel meer. Verhandelinge en proefskrifte onder sy leiding uitgewerk, gee hiervan ruimskoots blyke - dit was $s y$ belangstellingsveld maar ook hulle s'n. 


\section{Verhouding tot studente}

Tipies van die werkkrag en taakbesef van Stoker was sy voortdurende weiering om sy leiding as dosent tot 'n formele kennisname van die studieresultate van studente in te krimp. Die formele benoeming en taakopgawe as leier by 'n projek is spoedig tot ' $\mathrm{n}$ gemeenskaplike informele ontdekkingstog verbreed - informeel, omdat dit deur 'n gemeenskaplike doelwit tot 'n gemeenskaplike ons-taak in plaas van 'n my-taak gestempel is. Die mooie van van sy verhouding tot sy studente was dat dit nie 'n blote saaklike, probleemgeoriënteerde relasie was nie maar dat menigeen 'n raadgewer ell ware vriend in hom kon vind, ja dikwels ook in die koesterende strale van die huislike kring opgeneem is. Dan het die kwaliteite van 'n veelsydige persoonlikheid in 'n nuwe beligting verder uitgestraal en ook menige student onvermoede fasette in eie persoonlikheid laat ontdek en tot groter hoogtes aangespoor. Stoker se trou en lojaliteit teenoor sy studente was uniek. Dit het saamgehang met sy vertroue in hulle. Daarby het hy 'n oop hartlike verhouding met sy studente besonder op prys gestel. In sy inougurele rede van 1930 (Die kriesis in die teenswoordige Sielkunde p.33) het hy dit reeds só verwoord:

In die eerste plek aan $U$, wat in die verlede my kolleges geloop het en nog bywoon, my waardering vir die aangename gees, wat steeds in ons klasse geheers het. $U$ belangstelling, $U$ ywer, $U$ jeugdige entoesiasme was steeds vir my werk besielend.

Die roepingsbesef vir noodsaaklike arbeid in die koninkryk van God was vir Stoker sy dinamo om nuwe intellektuele weë te bewandel. Opgewonde ontdekkingsvreugde was daarvan die vrig. In menige geval het Stoker as promotor ewe hard as sy leerling - soms selfs harder - aan die werk gegaan om hom te vergewis van ' $n$ adekwate oriëntering tenl aansien van die betrokke tema. Die teenkant van die munt was natuurlik dat daarmee eie studieprojekte soms maandelang op halwe toere moes gaan draai - en kollegas en vriende rasend van ongeduld op resultate moes bly wag. In dergelike kontroverses was Stoker onversetlik. Ek weet ook van geen geval waar hy die aftog moes blaas nie! En vir vele bevreemdend was dan boonop die uiteinde: dat die wyere perspektief in eie visie, as resultaat van diverse detailondersoekinge met studente, Stoker ten slotte gelyk gegee het wat die aanwending van sy tyd betref. Nogtans bly dit 'n verlies vir die wetenskaplike wêreld dat menige manuskrip nie afronding bereik het nie en het dit hoog tyd geword dat ongepubliseerde argiefstukke aandag ontvang.

\section{Akademikus en dosent: enkele kenmerke}

Met 'n buitengewoon sterk en taai gestel, gekombineer met 'n streng mentale dissipline, toewyding en determinasie, het hy oor dekades 'n verstommende werksywer volgehou. Op sy eie het hy dekades lank ' $n$ wye verskeidenheid filosofiese 
deelwetenskappe vir voor- en nagraadse studente ontsluit. Sy veelsydigheid, breë vorming en wye belesenheid was veral vir die oopbreek van interdissiplinêre vraagstukke belangrik en nuttig. Sy besondere gawe om die rol van filosofiese persoonlikhede te vertolk en 'n kritiese diskussie te ontlok, het sy klasse 'n belewenis gemaak. As dosent het Stoker sy studente besiel omdat hy self 'n rolmodel van toegewyde studie was en goed voorbereid sy klasse aangebied het. Vanuit sy roepingsbesef was dit vir hom vanselfsprekend. Vir die toeskouer bly dit ' $n$ raaisel hoe hy dít alles kon hanteer en dan nog daarby gereelde toesprake en voordragte reg oor die land kon inpas om sy mense vanuit 'n CalvinistiesChristelike wortel geestelik weerbaar te maak. Dit is alleen daaruit verklaarbaar dat hy sy taak as akademikus en dosent só breed opgevat het dat hy naas sy formele verantwoordelikheid vir studente aan die universiteit(skollege) van Potchefstroom tewens 'n onsigbare landswye teikengroep op die hart gedra het. Die merkwaardige is dat hierdie werklus ook tot op gevorderde leeftyd volgehou kon word.

Dit bring my by die 'motor' en 'ratkas' agter sy optrede as geleerde. Stoker het akademiese arbeid as ' $n$ voorreg en kreatiewe roeping gesien en met volle inset uitgeleef: 'roeping' was die kragbron agter elke ondersoek, 'voorreg' die aanpasser wat die energie van sy denke in verskillende intellektuele projekte gekanaliseer en prioriteitstellend momentum verleen het. Weber het met sy 'Calvinistiese werksetiek' maar 'n klein, verskraalde en vertekende faset van die religieuse en kulturele dimensie van hierdie grondmotief aangevoel. Inherent hieraan was ook Stoker se opvoedkundige perspektief en beleid. Reeds uit sy studentetyd dateer ' $n$ spesiale belangstelling vir Pedagogiek en die didaktiese faset onderliggend aan die doseer van Filosofie. Stoker se opvoedkunde-praksis was sodanig dat promovendi duidelik die stempel van die meester dra, maar tegelykertyd onderling die verskille van 'n individuele aanpak toon. Sover my kennis strek, het geen enkele leerling aan ' $n$ konfrontasie met die grondbeginsels van 'n Calvinistiese filosofie ontkom nie - maar dan 'n persoonlike konfrontasie: meelewend, korrigerend, afwysend waar nodig. 'n Versoeking wat in die huidige tyd hier en daar aan bekoring wen, naamlik om die doseer van 'n kursus die basis van eie studie en beskouing te maak, het blykbaar geen aantrekkingskrag op Stoker kon uitoefen nie. As 'n voortdurende student het hy hom wysgerig so wyd moontlik, met groot ywer ook buite landsgrense, probeer oriënteer ten aansien van die wysgerige literatuur en die hooftendense daarin en jaarliks getas na weë om sy leerlinge didakties daarvan die vrugte te laat pluk. Waarskynlik is dit mede hieraan te danke dat Stoker die in soveel opsigte verlammende werking van die afgelope wêreldoorlog kon oorbrug, en selfs van sy belangrikste studies in die twee dekades daama kon lewer. 


\section{Opvoedkundige perspektief en beleid}

Stoker se opvoedkundige perspektief is grondig gevorm deur begaafde onderwysers aan die Duitse skool te Johannesburg, dosente aan die Literariese Departement van die Teologiese Skool op Potchefstroom en aan die P.U.K., asook verskeie semesters Filosofie-, Opvoedkunde-, Sosiologie en Psigologiestudie te Keulen en Berlyn by Max Scheler en ander vooraanstaande Duitse geleerdes. 'n Mens sou dit generaliserend kon saamvat as die 'kontinentaal-Europese' inslag van Stoker se akademiese werksaamheid en van sy doseer- en onderrigstyl. Noukeurigheid, eksaktheid, veeleisende standaarde en deurlopende kontrole en teksverbetering vorm daarvan steunpilare. Van Stoker se opvoedkundige teorie kan ek hier alleen maar nog een faset na vore haal: 'n dinamiese kyk op die potensialiteite, vorming en vordering van die individuele student. Naas waardering vir en erkenning van 'n opgaande grafiese lyn, het Stoker tewens as beginsel daarvan uitgegaan dat die beoordeling vanuit 'n totaliteitsoorsig gekontroleer word om die eensydige indruk wat geisoleerde toetse op diverse terreine kan laat, vanuit die geheel te balanseer.

Dat in die hanteer van sy opvoedkundige strategie ook ruimhartigheid en mensekennis 'n rol speel, het ek in 1955 'aan eie lyf' ondervind. In 'n seminaar moes ek 'n referaat oor Bergson lewer. Ek glo nie die vurige voordrag het Bergson se élantema in die sfeer van die indifferentia laat hang nie. Kritiese opmerkings van 'n medestudent het gevolg, en daarna van Stoker, afgesluit met 'n wye omraming deur die leermeester. Tot besluit was daar die vraag hoe ek die betrokke visie op die tydsbeskouing van Bergson verwerf het. Sonder verdere nadenke was my antwoord: studie van Bergson. Met die repliek 'so sien ek dit ook', was die klas ten einde. Eers maande later het my oë daarvoor oopgegaan in watter mate ek onbewus Stoker se tydsanalises in my studie verwerk het - én dat die leermeester gemerk het dat sy leerling nog nie ryp was om eie aflanklikheid te besef en die fondament van eie denke te peil en krities te toets nie! Praktiese leiding van die logiese funksie in die filosofie verg méér as maar die toepas van die reëls van 'n formele logika - dit verg kemnis, mensekennis, opvoedkundige kennis én 'n prosesmatige begeleidende slyping.

\section{1. 'n Pionier van wysgerige vaktaal in Afrikaans}

Die betekenis van Stoker se publikasies vir die ontwikkeling van 'n wysgerige vaktenninologie in Afrikaans word in breë kring erken. Sy voordragte was in hierdie opsig nie minder essensieel nie. Gedeeltelik hang dit saam met sy werkmetode. Hierby het 'n belangstelling vir die klassieke tale - deur Wilamowitz en ander in Duitsland nog verdiep en verbreed - stimulerend en kultiverend gewerk op 'n natuurlike aanvoeling vir die belang van die woord in die wysgerige denke. 
In menige voorstudie kon lexica gevolglik nuttige diens bewys by die aftasting van die moontlikhede van taal en begrip asook die linguale gekompliseerdheid van bepaalde vraagstukke. Sprekende voorbeelde hiervan is die mooi vondste in sy navorsing oor die tydsproblematiek, gedeeltelik gepubliseer in "Die problematologie van die tydsvorme" en "Gelyktydigheid". Op verskillende wyses het Stoker sy studente bewus gemaak dat skerp en kreatiewe denke belang het by die slyp van die taalinstrument.

Terselfdertyd het Stoker taal ook negatief as korreksie en toets van eie denkresultate aangewend deur die houdbaarheid van eie visie af te tas aan die sinvolle uitdrukkingsmoontlikheid in 'n vreemde taal. Elke nagraadse student sal onthou hoe dikwels Stoker gedurende 'n klas na woordeboeke en ensiklopedieë in sy elegante en stylvolle 'boekenmolen' getas het om die betekenisnuanses en reikwydte van wysgerige begrippe te vergelyk en verder af te weeg, dikwels ook oorspronklik uit te brei. Die student moes leer filosofeer deur die slyping van begripsapparaat en uitdrukkingsvaardigheid. Tot op hoë leeftyd het Stoker self vernuftig en kreatief nuwe vakterme geskep om presies en noukeurig aan te dui wat hy op oog gehad het en wat hy sinvol aan ander wou kommunikeer (bv. terme uit sy latere deontologie, soos idion).

Etimologiese vingerwysings is in gepaste gevalle met skerpsinnige vernuf opgevolg en filosofies oopgekap - byvoorbeeld probleem as ' $n$ 'ontdek' en 'vind' (in samehang met sy visie op kennis as antwoord: Oorsprong en rigting, 1:168 voortaan afgekort $O \& R$ ). Die woord probleem duik naamlik terug na die Griekse term pro-ballein: dit wat voor jou voete gewerp is. 'n Tweede kostelike voorbeeld is die term 'idion' $(O \& R, 2: 337)$. Met sy kenmerkende skerp onderskeidingsvermoë en presiese styl verduidelik Stoker $(O \& R, 1: 234)$ idion en die daarmee verwante term idiostansie só:

Idion is enigiets in en van die kosmos wat kenbaar is, maar afgesien van sy verhouding tot die mens. Dit vervang die meersinnige en teoreties oorbelaste terme soos 'data', 'gegewens', die 'voorhandene', 'objekte', 'Gegenstände', 'verskynsels', 'fenomene', 'ervaring', ens., wat bowendien 'n relasie tot die mens veronderstel; maar dit vervang ook die meersinnige en teoretiese, oorbelaste terme soos 'dinge', 'sake', 'stande van sake', 'gang van sake', 'syndes', ens., ook omdat hulle nie die eie eienheid van 'n idion tot uitdrukking bring nie. Onder die 'idionne' tref ons 'idio-stansies' aan, nl. stof, plante, diere en mense, wat weens hul relasionele afgerondheid van ander idionne onderskei behoort te word.

Ruimte laat hier nie 'n linguisties verantwoorde oorsig en analise toe nie. Ek volstaan met 'n kort illustratiewe toeligting, waarby die voorbeelde op gevoel af onder drie rubrieke gelys word (maar waarskynlik in meer as een tuishoort). 


\section{(1) Nuwe (of waarskynlik nuwe) terme:}

Dit sluit in merkwaardige neologismes soos 'beantwoordenheid' $(O \& R, 1: 172)$; 'hapantiese' (= alomvattende) bepalings; 'hiperdoks' (O\&R, 1:186,189,194); 'idion' , 'idiostansie'; 'na-spronklik' $(O \& R, 1: 173)$; 'outoquaerie' $(O \& R, 1: 168)$; 'teale' verhouding (van 'theos' $=\mathrm{God}-O \& R, 1: 272)$.

Kom ons bekyk twee hiervan. Reeds vroeg in die geskiedenis van die filosofie het die logies-teenstrydige die aandag getrek - die haas wat die skilpad met voorsprong nie kan inhaal nie, die stilstaande vlieënde pyl en so meer. Van dit wat in stryd met die menslike verstand is (paradoks), onderskei Stoker dit wat die menslike verstand te bowe gaan (hiperdoks): enersyds gaan Gods voorbeskikking oor alles en tog het God nie skuld aan die menslike sondeval nie, en andersyds is die mens verantwoordelik en het tog volledig skuld aan die sondeval. 'n Tweede pragvoorbeeld is die tern na-spronklik. Menslike vryheid as heerskappy, as antwoord, veronderstel 'n verband tussen vryheid en verantwoording (as terugslag van die antwoord op die antwoord $-O \& R, 1: 171$ ): menslike antwoording is onties óórspronklik, verantwoording egter onties ná-spronklik: 'n eerste en 'n laaste sprong. Hierdie linguaal oopgevoude insig bied 'n nuwe instrument om 'n faset vall die kontemporêre filosofie te verstaan.

(2) Gebruik van bestaande woorde met 'n nuwe of verdiepte betekenis, of ook met 'n aangepaste betekenis ter vervanging van ander vakterme:

Hoe Stoker taalvormend ' $n$ diepere dimensie in die betekenis van 'n woord ontsluit, blyk byvoorbeeld uit sy hanteer van die term 'kontingensie' (WAT, 7:257), wat sowel vir die natuur- as geesteswetenskappe belangrik is en toenemend filosofies gelade raak. 'n Eie konnotasie ontwikkel ook by woorde soos 'antwoorder', 'antwoording' (in samehang met roeping en sorg) maar ook 'wanwoord' $(O \& R, 1: 170)$; 'deontiese bepaling', 'deontiese' wetenskappe, 'deontiek', 'Deontologie' - terme wat die vraagstuk van behorenseise anspreek $(O \& R$, 2:181 e.v.); 'eiestandigheid' (i.p.v. outonomie); 'heerskap', 'heerskappy', 'heerwees' $(O \& R, 1: 165)$, wat nou saamhang met die dienende en sorgende fokus van sy roepingsleer, 'ostensief' = 'n tonende identifikasie ('n belangrike term uit sy laaste fase); 'persoonsbehartiging' ( $O \& R, 1: 251)$, 'self-behartiging' $(O \& R, 255)$ of ook 'liefdesbehartiging' $(O \& R, 1: 258)$ as kern van die sedelike, wat nou verwant is aan 'persoonsliefde' (vroeër persoonlikheidsliefde genoem - $O \& R, 1$ : 249). 'n Enkele toeligtende opmerking: Stoker onderskei sy diafanerotiese metode as fenomenologiese wesenskou van ander fenomenologiese en transendentale metodes $(O \& R, 1: 239 ; 2: 334)$. Hierdie metode gee erkenning aan die openbaring ('fanerosis') en is 'n wesens-skouende, 'n insienende, 'n in-tuï-tiewe, 'n deur-('dia'-)skouende metode wat syns insiens beter aan die kenbare - en wel die self-evidente self - reg laat geskied. 


\section{(3) Gebruik van woorde (of woordkombinasies) in 'n nuwe konteks:}

Besonder interessante gesigspunte kom na vore in die gebruik van terme soos 'begerigheid' - die begeerte onder leiding van die sondige natuur van die mens $(O \& R, 1: 200)$; 'grond' en 'oorsaak' $(O \& R, 1: 160)$ - as instrumente om uit die antinomie van menslike vryheid en wet te ontsnap; só ook 'kiesmoontlikheid' en 'wetsvervulling' (O\&R, 1:164); 'onontkombaarheid' en 'onoortreebaarheid' (O\&R, 2:396); 'ontwaring' en sy verband tot ervaring en interpretasie $(O \& R$, 2:354 e.v.). Werklik interessant is sy siening oor 'probleemsiening' en 'probleemontdekking' ( $O \& R, 1: 176)$ : eersgenoemde kan deur sy agtergrondbepaling verkeerd wees, nie aan die ontdekte probleem beantwoord nie en so 'n valse probleemstelling in die hand werk met 'n onjuiste probleemoplossing as gevolg.

\section{Raamwerk, vertrekpunt en praktiese betekenis van Stoker se koersduiding}

Stoker se akademiese lewe was ryk gevarieer en danksy 'n besonder sterk gestel en intellektuele speurwil ook geseënd met 'n wysgerige ontwikkelingsgang van dekades. Die detailproblematiek hiervan is belangrik. In hierdie verband kan egter alleen opgemerk word dat die nuanseringe voltrek word binne die raam van 'n uitgebreide analise van kosmiese dimensies en dat die motief van die 'skeppingsidee' 'n poging behels om 'n Christelike beoefening van die wysbegeerte te radikaliseer en ekspliseer. Globaal genome is my indruk dat hierby analise van afsonderlike dimensies sóver in 'n meer gevorderde stadium verkeer as die studie van die betrokke samehange daartussen - waar teoreties gesproke die crux van die vraagstuk geleë is. Indien ek my nie vergis nie, speel op die agtergrond hier die ideaal-tipiese metode 'n rol, dit wil sê begin by dit wat helder onderskeibaar is en skry dan vandaar na die meer problematiese voort. Die didaktiese waarde hiervan vir die ontwikkelende student is voor die hand liggend.

'n Praktiese konsekwensie van hierdie aanpak - én 'n entoesiastiese uitwys van die boeiende van die filosofie eerder as die tegnies moeilike en gevaarlike daarvan - is bowendien dat studente nie tot skepsis verlei word nie. Hieruit volg egter geensins die konklusie: en dus dogmatiese indoktrinasie deur die (verder gevorderde) dosent nie. Persoonlike deurdenking en stellingname van die kant van die student was altyd uitgangspunt, ewe vanselfsprekend as wat die leermeester 'n eie oorspronklike opvatting voordra en leiding bied. Van groot belang in 'n tyd wat uit afkeer van rasionalistiese beginsels 'n teenkanting teenoor beginsels as sodanig kweek, skyn my die klem en nuansering wat Stoker in sy doseerpraktyk op beginsels en veral dan Calvinistiese prinsipiële denke gelê het. In dié opsig staan hy in die verlengde van die generasie van Kuyper, Bavinck en Geesink. Gekonfronteer met 'n devaluasie in erkenning en waardering van die wet soos dit in beginsels stol, sal 'n jongere generasie myns insiens die tyds- 
gebonde en durende faset van beginsels geestelik moet kan sif en in die toekoms nog met vrug van die wysgerige arbeid van H.G. Stoker kennis kan neem.

'n Oop oog vir en klem op beginsels impliseer nie opsluiting in 'n ivoortoring nie. So het meer as een voordrag en geskrif ' $n$ onverwagte praktiese betekenis. In dié sin sluit talle temas aan by die probleme en node van die Suid-Afrikaanse milieu. Grondgedagtes van die stryd om die ordes, Christelike wetenskapsbeoefening, roeping, vryheid, aard en karakter van die universiteit, ensovoorts, lewer hiervan oorvloedige illustrasie. Deur diẻ opset werk die praktiese betekenis hiervan ook buite die suiwer akademiese sfeer deur, uiteraard verskillend mede na gelang van die betrokke tema. Sommige is seker ook meer tydsbepaald as andere. Daaroor nog 'n enkele opmerking.

\section{Tematisering by Stoker}

By sommige temas het Stoker die grondlyne reeds vroeg skerp gesien en deur die jare byna ongewysig behou en aan sy studente voorgehou - so byvoorbeeld die betekenis van die Calvinisme vir wetenskap en volkslewe. Met ander temas het Stoker jarelang - soms de novo - bly worstel. Ek dink onder andere aan sy intensiewe studie van die filosofie van H. Dooyeweerd en D.H.Th. Vollenhoven; aan die probleem waarin die Christelike karakter van die verskillende wetenskappe gesoek moet word indien veronderstel word dat wysbegeerte die grondslae van die vakwetenskappe lê en op sy beurt afhanklik is van die teologie vir sy grondideë; aan die ensiklopedie van die wetenskappe en die onderlinge wisselwerking van die afsonderlike wetenskappe, en so meer.

Sommige temas het van tyd tot tyd verskerpte aandag ontvang of op die agtergrond geskuif. Uit my beginjare herinner ek my byvoorbeeld vermelding van die aanname van 'n formele en materiële prinsipe by die uiteensetting van die Wysbegeerte van die Skeppingsidee. Die fondament hiervan het my ontglip en nooit by my ' $n$ afgeronde prentjie geword nie. Ek vermoed dat dié punte toe vir Stoker óf vanselfsprekend was óf nie tematies-aktueel nie - dit wil sê dat ander gedeeltes van sy wysbegeerte toe primêre aandag en eksplikasie geverg het. Dat ek in dié jare nie daarin kon slaag om die gronde vir bostaande aanname op te spoor nie, het egter nie 'n verstaan van sentrale gedagtes op ander punte onmoontlik gemaak nie. Die filosofie van Stoker was diep - of hoog, soos 'n mens maar die metafoor wil toespits! - , veelkantig en ingewikkeld maar tog oorsigtelik met ' $n$ innerlike logiese orde, soms wel moeilik, maar nie onbegryplik nie.

\section{Basiese betekenis vir die student}

Terugskouend sou ek Stoker se betekenis vir sy studente só kon saamvat: wat ons in Stoker steeds waardeer het was sy breë vakoriëntasie, essensiële feite- 
konsentrasie en oorsigtelike presentasie. Dat in dit alles die strewe na 'n Christelike beoefening van die wetenskap evident was en deeglik begrond en gemotiveer is, het 'n leerskool by H.G. Stoker destyds tot 'n voorreg gemaak, en tans tot ' $n$ dankbare herinnering. 